\title{
PENGARUH TERPAAN IKLAN NACIFIC DI INSTAGRAM TERHADAP KEPUTUSAN PEMBELIAN PRODUK NACIFIC PADA FOLLOWERS AKUN (a)NACIFICOFFICIAL.ID
}

\author{
Didiek Tranggono $^{1}$, Ajeng Nidita ${ }^{2}$ Putri, Juwito $^{3}$ \\ ${ }^{1,2,3}$ Universitas Pembangunan Nasional "Veteran" Jawa Timur \\ 12di2ektranggono@gmail.com, ${ }^{2}$ nidita@gmail.com, 3juwito@gmail.com
}

\section{Article Info}

Article history:

Received 15 Agustus 2020

Accepted 10 September 2020

Published 1 Oktober 2020

\section{Keyword:}

Iklan, Terpaan Iklan, Instagram, Keputusan Pembelian

\section{Abstract}

This research discusses the effect of exposure to nacific advertisements on instragram on purchasing decicions for nacific prodctson followers of he @ nacificofficial.id. This research uses quantitative approach and the analytical method used is multiple linear regression. The object of this research is Jang Hansol version of Nacific ad which about answers question about 'Fresh Herb Origin' product. Meanwhile, the subject is followers Nacific's official account on Instagram, @ nacificofficial.id who have watched the ad. Primery data collection using a questionnaire to 100 respondents. The results showed that exposure of Nacific ad on Instagram has positive influence on purchase decision of the advertised product. Thus, $\mathrm{H}_{1}, \mathrm{H}_{2}$ and $\mathrm{H}_{3}$ are accepted, that means frequency, duration and intensity have influence on purchase decision which have indicators: product choices, brand choices, supplier choices, time of purchase, purchase quantity and payment method.

Penelitian ini membahas tentang pengaruh terpaan iklan nacific di instagram terhadap keputusan pembelian produk nacific pada followers akun@nacificofficial.id. Penelitian ini menggunakan pendekatan kuantitatif dan metode analisis yang digunakan ialah regresi linier berganda. Objek penelitian ini ialah iklan Nacific versi Jang Hansol yang menjawab pertanyaan seputar produk 'Fresh Herb Origin'. Sedangkan, subjek penelitian ini ialah followers akun resmi Nacific di Instagram yakni @ nacificofficial.id yang telah menonton tayangan iklan tersebut. Pengumpulan data primer dengan menggunakan kuesioner kepada 100 orang responden. Hasil penelitian menunjukkan bahwa terpaan iklan Nacific di Instagram memiliki pengaruh positif terhadap keputusan pembelian produk yang diiklankan. Sehingga, $\mathrm{H}_{1}, \mathrm{H}_{2}$ dan $\mathrm{H}_{3}$ diterima, yakni frekuensi, durasi dan intensitas memiliki pengaruh terhadap keputusan pembelian yang memiliki indikator; pilihan produk, pilihan merek, pilihan penyalur, jumlah pembelian, waktu pembelian dan metode pembayaran.

\section{Editorial Office:}

Program Studi Ilmu Komunikasi, Fakultas Dakwah dan Komunikasi, UIN Sunan Ampel Surabaya. Jl. Ahmad Yani 117 Surabaya, Jawa Timur, Indonesia.

Email: jurnalilkom@uinsby.ac.id 


\section{Pendahuluan}

Perkembangan teknologi informasi dan komunikasi mempengaruhi sangat mempengaruhi pola komunikasi dan gaya hidup yang dilakukan oleh manusia. Salah satu produk dari komunikasi yang berkaitan dengan pemasaran ialah iklan. ${ }^{1}$ Dunia periklanan pun mengikuti perkembangan yang ada karena tidak dapat lepas dari media yang berfungsi sebagai wadah dari iklan tersebut. Kini, pilihan media yang dapat digunakan semakin variatif dengan munculnya suatu "media baru" yakni media daring atau dalam jaringan (internet). Memasuki abad ke-21 sejumlah website, termasuk Google Search atau mesin pencarian Google memiliki peran tersendiri dan memulai perubahan dalam dunia periklanan online yang menandai kebangkitan dari tren periklanan interaktif dengan menggunakan internet. ${ }^{2}$

Menurut Denis McQuail, ${ }^{3}$ "media baru" merupakan perangkat media elektronik baru yang mencakup beberapa sistem teknologi, di antaranya yakni sistem transmisi, sistem miniaturisasi, sistem penyimpanan dan pencarian informasi, sistem penyajian gambar, serta sistem pengendalian oleh komputer.

1 Anisatus Shauma dan Zainal Abidin, Efektivitas Iklan Politik di Televisi (Studi Deskriptif Kuantitatif Efektifitas Iklan Politik Aburizal Bakrie Versi Motivasi Anak Indonesia Pada Pemilih Pemula di Surabaya, Jurnal Imu Komunikasi 7, no 2 (Oktober 2015): 4. http://eprints.upnjatim.ac.id/7017/1/1.JURNAL_ Zainal_2.pdf

${ }^{2}$ Muhammad Jaiz, Dasar-Dasar Periklanan, (Yogyakarta: Graha Ilmu, 2014), 5.

${ }^{3}$ Denis McQuail, Teori Komunikasi Massa: Suatu Pengantar, (Jakarta: Erlangga, 1991), 16-17.
Implementasi dari adanya media baru ialah dengan munculnya suatu media berbasis digital yang memanfaatkan internet, biasa kita sebut sebagai media sosial. Terdapat berbagai macam aplikasi media sosial yang memiliki karakteristik berbeda. $^{4}$ Ada yang lebih fokus pada fotografi, di mana kontennya berupa foto, video dan sebagainya, sedangkan ada yang lebih fokus pada pertukaran pesan seperti chatting. Salah satu aplikasi media sosial yang banyak digunakan ialah Instagram.

Menurut Landsverk dalam buku The Instagram Handbook: 2014 Edition, Instagram adalah jejaring sosial yang paling populer digunakan untuk berbagi foto maupun video. Pengguna dapat mengunggah foto secara digital lalu menerapkan filters untuk mengedit penampilan mereka, dan membagikan foto tersebut ke pengguna yang lain. Selain untuk hiburan, Instagram kerap dimanfaatkan sebagai katalog produkproduk yang dipasarkan. Salah satu brand atau merek yang menggunakan Instagram sebagai media untuk beriklan ialah Nacific, merek produk perawatan kulit yang berasal dari Korea Selatan dan telah melakukan penjualan secara resmi di Indonesia.

Nacific didirikan pada tahun 2014. Pada tahun 2016, merek ini mengekspor produk-produk perawatan kulit mereka ke beberapa negara seperti Taiwan, Hong

\footnotetext{
4 Achmad, Z. A., \& Setiyanti, O. W. The Effectiveness of Use of Soundcloud Application for Promoting Pop Punk Songs and Music, Bali International Seminar on Science and Technology, (2015): 61 , www.engadget.com/2012/12/07/editorial-
} 
Kong, Kamboja, Amerika Serikat, Malaysia dan Indonesia. Tahun 2019, Nacific membuka perwakilan resmi mereka di Indonesia dengan nama Nacific Indonesia, diawali dengan membuat akun Instagram yakni@nacificofficial.id dan akun resmi di salah satu platform belanja online yakni Shopee, dengan nama toko Nacificofficial.id. Sejauh ini, penjualan yang dilakukan berupa online dengan pengiriman produk dari Korea Selatan langsung dan juga dapat dijumpai pada beberapa drugstore makeup di department store di kota-kota besar. Sejauh ini, Nacific belum membuka official outlets atau gerai resmi mereka di Indonesia.

Pada Instagram, terdapat fitur "akun bisnis" yang membantu penjual untuk mempromosikan produk-produknya. Diketahui bahwa salah satu fungsi Instagram beberapa tahun terakhir ini adalah sebagai katalog iklan. Ada banyak online shop dan berbagai brand, mulai dari fashion, beauty, hingga furniture yang menggunakan jasa Instagram sebagai media promosi. ${ }^{5}$ Seperti yang dilakukan oleh Nacific, yang menggunakan Instagram sebagai katalog produk-produk mereka, dengan menampilkan konten berupa foto maupu video yang berisi informasi mengenai produk yang ditawarkan. Nacific juga beriklan di Instagram (iklan berbayar) sehingga iklan mereka dapat ditayangkan pada Instagram

5 Nadya Paramitha, 5 Fitur Terbaru dari Platform Media Sosial Favorit Ini Berguna Banget!, Januari 1, 2020, https://journal.sociolla.com/lifestyle/fitur-baruplatform media-sosial/
Story maupun di beranda, yakni tempat unggahan-unggahan foto maupun video akun yang diikuti ditampilkan. Hal ini disebut sebagai Iklan Instagram atau Instagram Ads. Tentu kelebihan dari menggunakan fitur ini ialah iklan dapat diterima oleh target audiens sesuai yang diharapkan atau tepat sasaran karena adanya pengaturan tentang kriteria audiens yang dapat ditetapkan oleh pengiklan.

Peneliti ingin meneliti iklan Nacific versi Jang Hansol di Instagram yang mengiklankan tentang salah satu rangkaian produk Nacific yakni 'Fresh Herb Origin'. Selain diiklankan oleh Instagram pada fitur Iklan Instagram, iklan ini juga diunggah pada akun resmi Nacific di Instagram sebagai konten. Iklan berdurasi 15 detik ini berisikan tentang jawaban mengenai pertanyaan yang sering dilontarkan kepada pihak Nacific yakni, "Apakah Fresh Herb Origin Serum boleh digunakan pada kulit berjerawat?" dan pertanyaan tersebut dijawab oleh Jang Hansol yang merupakan brand ambassador Nacific Indonesia. Ia menjelaskan bahwa 'Fresh Herb Origin Line' sudah lulus uji klinis nonkomedogenik sehingga dinyatakan aman digunakan untuk kulit berjerawat. Selain itu terdapat URL website ditandai dengan ikon yang bertuliskan "Selengkapnya", dan jika diklik akan tersambung ke situs belanja online Shopee milik Nacific yang menampilkan produk sesuai dengan yang diiklankan di Instagram. Hal tersebut tentu memudahkan calon pembeli untuk melakukan pembelian online secara cepat dan mudah. 
Peneliti ingin mengetahui apakah iklan yang menampilkan seseorang brand ambassador memiliki pengaruh tersendiri kepada konsumen yang melihat iklan tersebut. Akan tetapi perlu digaris bawahi bahwa peneliti ingin meneliti pengaruh dari iklan Nacific bukan pengaruh dari seorang brand ambassador yang dimiliki Nacific. Pengaruh yang ingin diteliti tentu berhubungan dengan keputusan pembelian terhadap konsumen yang telah melihat tayangan iklan tersebut. Di mana keputusan pembelian ialah salah satu dari sekian banyaknya perilaku konsumen yang tentunya diharapkan oleh produsen.

\section{Kajian Pustaka}

\section{Terpaan Iklan}

Menurut Shimp ${ }^{6}$, terpaan ialah ketika konsumen berinteraksi dengan pesan dari pemasar (mereka melihat iklan majalah, mendengar iklan radio, dan lain-lain). Terpaan merupakan kesempatan bagi pembaca, pemirsa, atau pendengar untuk melihat atau mendengar iklan. Yang berarti bahwa dilihat, atau didengar adalah tujuan penting perencana media yang mencoba cara terbaik untuk memaparkan audiens sasaran terhadap pesan dari iklan tersebut. ${ }^{7}$ Terpaan tidak menjamin akan memberikan pengaruh kepada konsumen yang terpapar mengenai pesan yang

${ }^{6}$ Terence A. Shimp, Periklanan \& Promosi: Aspek Tambahan Komunikasi Pemasaran Terpadu, Jilid 1 ed. 5, (Jakarta: Erlangga, 2003), 10.

7 Wells, William, Sandra Moriarty \& John Burnett. Advertisig Principles \& Practice 7th Edition, (New Jersey: Pearson Prentice Hall, 2006).

disampaikan, meski terpaan
merupakan tahap utama dari
memproses suatu informasi.
Sedangkan indikator terpaan iklan
adalah sebagai berikut:

a. Frekuensi

Frekuensi adalah jumlah keseringan seorang audience terkena terpaan media khususnya iklan dalam waktu tertentu. Tingkatan frekuensi yang dimiliki pemirsa tentu akan mempengaruhi mereka dalam hal mengingat pesan serta membangun kepercayaan terhadap merek dari produk yang diiklankan.

\section{b. Durasi}

Durasi iklan adalah seberapa lama khalayak memperhatikan iklan. Seberapa lama iklan dilihat, dibaca dan didengar. Sedangkan, durasi menonton ialah seberapa lama waktu rata-rata yang dihabiskan oleh khalayak ketika menonton iklan dalam waktu sekali penayangan. ${ }^{8}$

\section{c. Intensitas}

Intensitas merupakan seberapa dalam audiens ketika memperhatikan segala sesuatu yang disajikan oleh media massa. Sehingga intensitas menonton ialah seberapa besar perhatian yang diberikan oleh audiens ketika menonton tayangan tersebut.

${ }^{8}$ Muhammad Jaiz, Dasar-Dasar Periklanan, (Yogyakarta: Graha Ilmu, 2014), 15. 


\section{Keputusan Pembelian}

Menurut Lee dan Johnson ${ }^{9}$, keputusan pembelian merupakan suatu proses yang dipandang sebagai serangkaian tahap yang dilalui oleh pembeli dalam melakukan pembelian suatu produk maupun jasa. Proses keputusan pembelian tersebut melalui lima tahap, yakni sebagai berikut:

a. Pengenalan Kebutuhan/ Masalah

Tahap pertama yang dilalui oleh konsumen ialah pengenalan kebutuhan atau pengenalan masalah. Pada tahap ini, konsumen dipengaruhi untuk dapat mengenali kebutuhan yang dapat dipenuhi oleh produk yang diiklankan. ${ }^{10}$

b. Pencarian Informasi

Setelah mengenali masalah/mengenali kebutuhannya, konsumen akan mencari informasi tambahan seputar produk tersebut. Baik seperti kandungan yang ada di dalam produk, bahan produk, cara mendapatkan produk maupun manfaat-manfaat yang akan ia dapatkan.

c. Evaluasi Alternatif

Setelah berbagai informasi yang dibutuhkan terkumpul, maka selanjutnya pembeli akan melakukan evaluasi produk tersebut dengan mempertimbangkan berbagai hal

9 Monle Lee and Carla Johnson, PrinsipPrinsip Pokok Periklanan dalam Perspektif Global, (Jakarta: Kencana Prenada Media, 2011), 33.

${ }^{10}$ Damiati dkk., Perilaku Konsumen, (Depok: Rajawali Pers, 2017), 15. seperti kualitas, harga, waktu pengiriman dan lain-lain. Pada tahap ini sering kali dengan membandingkan dengan produk dari merek kompetitor.

d. Keputusan Pembelian

Setelah melakukan berbagai pertimbingan, tahap selanjutnya ialah konsumen memutuskan akan membeli produk tersebut atau tidak. Jika membeli, maka ada pertimbangan yang akan dilalui oleh pembeli lagi produk apa yang akan dibeli, dari merek mana, kapan membeli, di penjual mana ia akan membeli, dan sebagainya.

e. Evaluasi/ Perilaku Pascapembelian

Setelah melakukan pembelian suatu produk, secara sadar maupun tidak sadar konsumen akan melakukan evaluasi terhadap produk yang telah ia beli, atau yang biasa disebut sebagai perilaku pasca-pembelian. Hal ini lah yang menentukan konsumen akan melakukan pembelian ulang atau tidak, tergantung dari tingkat kepuasan konsumen terhadap produk dari suatu merek tersebut.

\section{Indikator Keputusan Pembelian} Menurut Kotler dan Keller ${ }^{11}$ dan Masharyono dik. ${ }^{12}$ terdapat enam

11 Philip Kotler and Kevin Lane Keller, Manajemen Pemasaran. Jilid 1 ed. 13, (Jakarta: Erlangga, 2012), 45.

12 Masharyono, Diyah Setyorini dan Intan Lina Katrin, Pengaruh Promosi Terhadap Keputusan Pembelian di Restoran Javana Bistro Bandung, (Bandung: Universitas Pendidikan Indonesia, 2016) 
indikator keputusan pembelian, yakni: pilihan produk, pilihan merek, pilihan penyalur, jumlah pembelian, waktu pembelian dan metode pembayaran. Berikut penjabarannya:

a. Pilihan Produk. Konsumen dalam memilih produk dari banyaknya pilihan produk ialah dengan melakukan berbagai pertimbangan. Pertimbangan tersebut berupa:

1) Keunggulan produk: Bagaiamana kualitas produk tersebut, apakah sesuai dengan apa yang diinginkan konsumen.

2) Manfaat produk: Manfaat apa yang akan didapatkan konsumen saat menggunakan produk tersebut, apakah sesuai dan dapat memenuhi kebutuhannya atau tidak.

3) Pemilihan produk: pilihan yang telah ditetapkan oleh konsumen mengenai produk tersebut, apakah berkualitas sesuai yang diharapkan dan bermanfaat.

b. Pilihan Merek. Setelah menetapkan produk, selanjutnya ialah menentapkan pilihan merek. Berikut bagaimana konsumen memilih suatu merek di antara pilihan merek-merek yang lain:

1) Ketertarikan pada merek: Konsumen merasa tertarik terhadap suatu merek karena image/citra merek tersebut yang dianggap menjadi nilai tambah terhadap suatu produk.
2) Kebiasaan pada merek: Konsumen dapat memilih merek tertentu karena merasa telah terbiasa dengan kehadiran merek tersebut, dan cenderung akan memilih produk dari merek yang lebih ia kenal tersebut.

3) Kesesuaian harga: Konsumen lebih memilih produk dari suatu merek yang ia rasa memiliki harga yang sesuai dengan kualitas atau manfaat yang dimiliki oleh produk tersebut.

c. Pilihan Penyalur/Penjual. Dalam memilih penjual mana yang akan dipilih oleh konsumen ketika melakukan pembelian, dipengaruhi oleh berbagai faktor yang menjadi pertimbangan. Yakni sebagai berikut:

1) Lokasi penjual tersebut, apakah dapat dijangkau dengan mudah dan memerlukan waktu yang sebentar atau singkat. Semakin mudah dijangkau, konsumen akan merasa lebih nyaman mengunjungi penjual tersebut.

2) Pelayanan yang didapatkan dari penjual tersebut, apakah memiliki pelayanan yang baik, sangat memuaskan ataupun sebaliknya.

3) Apakah produk yang akan dibeli tersedia dan memiliki stok yang baru atau stok yang banyak pada penjual tersebut. 
d. Jumlah Pembelian. Dalam melakukan pembelian, kuantitas atau jumlah produk yang akan dibeli tentu masuk ke dalam pertimbangan. Keputusan dalam menentukan jumlah pembelian pun berbeda-beda, yakni sebagai berikut:

1) Konsumen memutuskan membeli produk berdasarkan keinginan berapa banyak produk yang harus dibeli.

2) Konsumen memutuskan membeli produk sebagai persediaan (akan digunakan untuk waktu yang akan datang) sehingga mempertimbangkan jumlahnya dengan teliti.

e. Waktu Pembelian. Konsumen tentu akan mempertimbangkan waktu yang tepat dalam melakukan pembelian produk. Setiap konsumen tentu memiliki pertimbangan waktu yang berbeda-beda dan disebabkan oleh:

1) Sesuai dengan kebutuhan, saat konsumen merasa harus membeli produk dalam waktu dekat untuk memenuhi kebutuhan tersebut.

2) Keuntungan yang akan didapatkan konsumen jika membeli produk dalam waktu tertentu, misalnya saat sedang promo atau diskon dan sebagainya.

3) Alasan pribadi konsumen juga menjadi pertimbangan untuk menentukan waktu pembelian produk, bisa saja produk tersebut untuk pemuas keinginan semata bukan karena kebutuhan.

f. Metode Pembayaran. Konsumen akan menetapkan metode pembayaran mana yang akan digunakan saat melakukan pembelian. Yang menjadi pertimbangan ialah seperti kemudahan, apakah efisien dan efektif, atau sebagainya. Metode pembayaran yang dapat dijumpai ialah seperti pembayaran tunai, kartu kredit, kartu debit, mobile banking, intenet banking dan sebagainya.

\section{Teori S-O-R}

Teori S-O-R dikemukakan oleh Hovland, et al (1953). Unsur-unsur dalam toeri S-O-R ialah: Stimulus (S) yang merupakan rangsangan yang tertuju pada pesan, Organisme $(\mathrm{O})$ yang tertuju pada komunikan atau seseorang yang terkena rangsangan, serta Response ( $\mathrm{R})$ atau biasa dikenal sebagai efek yang ditimbulkan dari adanya rangsangan tersebut. Asumsi dasar dari teori ini ialah penyebab terjadinya suatu perubahan sikap yang dimiliki oleh individu disebabkan oleh kualitas rangsangan berupa pesanpesan yang ditujukan kepada individu atau organisme tersebut.

Akan tetapi, walaupun perubahan sikap tersebut tergantung dari stimulus, tetapi hal ini dapat juga dipengaruhi oleh proses yang terjadi di 
dalam diri individu atau organisme itu tadi. Menurut Effendy ${ }^{13}$ dalam tahapan organisme terdapat tiga proses yang terjadi yakni Perhatian, Pengertian dan Penerimaan. Stimulus yang berupa pesan dan disampaikan oleh kounikator kepada komunikan dapat memungkinkan untuk diterima maupun ditolak. Sebelum pesan itu dapat diterima/ditolak, maka komunikasi harus berlangsung dengan mendapatkan adanya perhatian dari komunikan. Setelah itu, komunikan akan berusaha mencerna pesan yang disampaikan, dan ia dapat saja mengerti dan memahami maupun sebaliknya. Komunikan tersebut menerima/menolak pesan. Jika menerima, maka terjadilah kesediaan komunikan untuk mengubah sikap. Begitupula dengan sebaliknya.

\section{Kerangka Berpikir}

Berikut bagan dari kerangka berpikir yang dilakukan oleh peneliti:

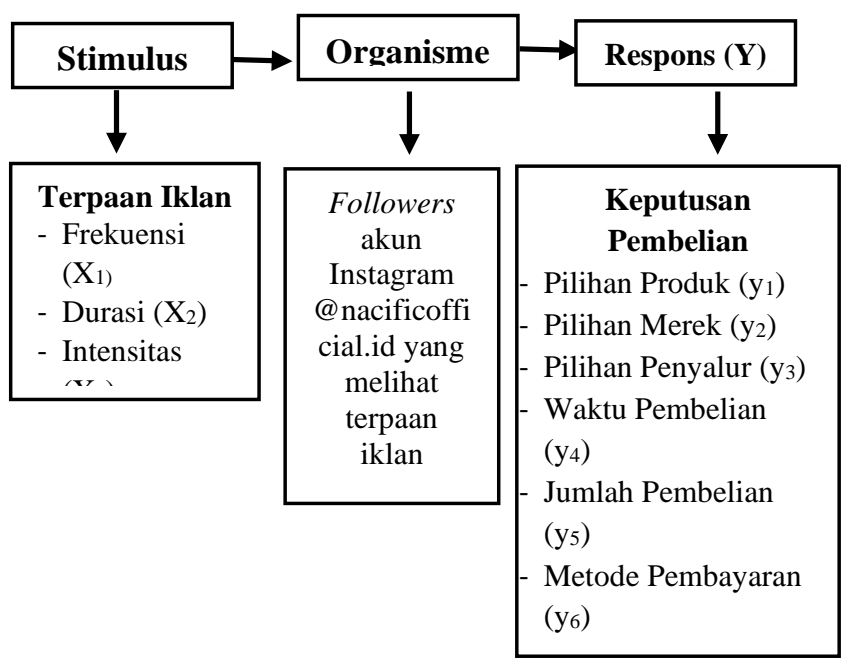

13 Onong Uchjana Effendy, Ilmu, Teori dan Filsafat Komunikasi, Bandung: Citra Aditya Bakti, 2000), 25.
Pada bagan kerangka berpikir diatas menjelaskan bahwa variabel bebas (X) pada penelitian yang dilakukan ialah stimulus (S) yang berupa terpaan iklan Nacific di Instagram versi Jang Hansol yang menjawab pertanyaan seputar produk Nacific yakni rangkaian seri Fresh Herb Origin. Peneliti menggunakan tiga variabel bebas yaitu frekuensi iklan $\left(\mathrm{X}_{1}\right)$, durasi organisme saat melihat terpaan iklan $\left(\mathrm{X}_{2}\right)$, dan intensitas organisme saat melihat terpaan iklan $\left(\mathrm{X}_{3}\right)$.

Organisme pada penelitian ini merupakan followers akun Instagram resmi milik Nacific yakni @ nacificofficial.id yang telah melihat atau menonton tayangan iklan Nacific yang dimaksud di Instagram. Sedangkan, untuk variabel terikat (Y) yang merupakan respons, ialah keputusan pembelian yang terdiri dari enam indikator yakni; pilihan produk, pilihan merek, pilihan penyalur, jumlah pembelian, waktu pembelian dan metode pembayaran.

\section{Hipotesis}

Berdasarkan kerangka berpikir di atas maka hipotesis dari penelitian ini ialah bahwa terdapat pengaruh antara terpaan iklan terhadap keputusan pembelian, dengan kaidah pengambilan keputusan sebagai berikut:

Terima $\mathrm{H}_{1} \quad$ : Terdapat pengaruh antara frekuensi menonton iklan Nacific di Instagram terhadap keputusan pembelian produk Nacific.

Terima $\mathrm{H}_{2}$ : Terdapat pengaruh antara durasi menonton iklan Nacific di Instagram terhadap keputusan pembelian produk Nacific. 
Terima $\mathrm{H}_{3} \quad$ : Terdapat pengaruh antara intensitas menonton iklan Nacific di Instagram terhadap keputusan pembelian produk Nacific.

Pada penelitian ini terpaan iklan Nacific sebagai variabel bebas (independen) yang terdiri dari frekuensi $\left(\mathrm{X}_{1}\right)$, durasi $\left(\mathrm{X}_{2}\right)$ dan intensitas $\left(\mathrm{X}_{3}\right)$ serta keputusan pembelian sebagai variabel terikat (dependen) atau bisa juga disebut variabel Y.

\section{Metode Penelitian}

Pada penelitian ini, metode penelitian yang digunakan ialah metode dengan pendekatan kuantitatif. Menurut Sugiyono $^{14}$ metode ini digunakan untuk meneliti suatu sampel dari populasi tertentu. Pengumpulan data dapat dilakukan dengan menggunakan bantuan dari instrumen penelitian, dan data yang dihasilkan pun berupa data kuantitatif atau data statistik. Jika kualitatif berbicara mengenai kedalaman data, maka kuantitatif berbicara mengenai keluasan data, sehingga pada metode ini menghendaki adanya sampel dari suatu populasi.

Dalam melakukan penelitian, peneliti menggunakan bantuan instrumen penelitian yakni kuesioner. Kuesioner sendiri merupakan kumpulan dari pertanyaan-pertanyaan terstruktur atau sistematis, di mana kuesioner ini akan disebarkan kepada para responden yang merupakan sampel dari populasi yang telah peneliti tentukan. Data yang berupa

14 Sugiyono, Metode Penelitian Bisnis (Pendekatan Kuantitatif dan R\&D), (Bandung: Alfabeta, 2010), 19. jawaban responden yang telah diperoleh akan dicatat, diolah dan dianalisis.

Populasi pada penelitian ini ialah followers akun Instagram resmi Nacific yakni@ @nacificofficial.id. Jumlah populasi sebanyak 188.420 followers. Data populasi yang digunakan berdasarkan pada data yang diakses pada tanggal 20 Februari 2020 pukul 14:30 WIB. Sampel penelitian ini adalah laki-laki maupun perempuan yang mem-follow (mengikuti) akun resmi Nacific di Instagram yakni @ nacificofficial.id, dan pernah menonton terpaan tayangan iklan Nacific versi Jang Hansol yang menjawab pertanyaan seputar produk di Instagram. Laki-laki maupun perempuan yang dimaksud ialah dengan rentang usia sekitar 15 - 29 tahun. Menurut hasil survei APJII pada tahun 2018, pengguna internet didominasi oleh pengguna dengan rentang usia $15-29$ tahun. Pengguna dengan usia $15-19$ tahun, sebesar $91 \%$, pengguna dengan usia 19 - 24 tahun sebesar $88,5 \%$ dan pengguna dengan usia 25 - 29 tahun sebesar $82,7 \%$.

Peneliti menggunakan teknik analisis Regresi Linier Berganda untuk meneliti masing-masing pengaruh indikator pada variabel $\mathrm{X}$, yakni frekuensi $\left(\mathrm{X}_{1}\right)$, durasi $\left(\mathrm{X}_{2}\right)$ dan intensitas $\left(\mathrm{X}_{3}\right)$ terhadap variabel Y, yakni keputusan pembelian yang memiliki enam indikator $\left(\mathrm{y}_{1}, \mathrm{y}_{2}, \ldots, \mathrm{y}_{6}\right)$. Langkah pertama yang akan dilakukan ialah dengan mencari hubungan antar masing-masing indikator $\mathrm{X}$ dengan masing-masing indikator $\mathrm{Y}$, dan jika terdapat hubungan maka akan dicari apakah terdapat pengaruh atau tidak. Karena, jika antar indikator memiliki 
pengaruh sudah pasti adanya hubungan, akan tetapi dengan adanya hubungan belum pasti memiliki pengaruh. Sebelum melakukan teknik analisis regresi, peneliti melakukan uji validitas dan uji reliabilitas terlebih dahulu untuk menguji instrumen penelitian yang peneliti gunakan, yakni pertanyaan dalam kuesioner.

\section{Hasil Penelitian Dan Pembahasan}

\section{Uji Validitas}

Validitas menunjukkan seberapa jauh suatu alat pengukur itu dan mengukur apa yang akan diukur. ${ }^{15}$ Uji Validitas menggunakan rumus Korelasi Product Moment, dengan bantuan SPSS 26. Instrumen dikatakan valid jika, $r$ hitung > $\mathrm{r}$ tabel. Diketahui $\mathrm{N}=100$, nilai signifikasi $5 \%$ atau 0,05 maka diketahui $\mathrm{r}$ tabel ialah 0,195.

Hasil analisis menunjukkan masingmasing item/pertanyaan terkait variabel Frekuensi (X1), Durasi (X2), Intensitas (X3) dan Keputusan Pembelian (Y) memiliki nilai $r$ hitung $>r$ tabel, sehingga instrumen penelitian dikatakan valid.

\section{Uji Reliabilitas}

Uji reliabilitas dapat dilakukan setelah melakukan uji validitas atau jika alat ukur telah dinyatakan valid. Reliabilitas merupakan suatu nilai yang menunjukkan bahwa alat ukur yang digunakan ialah konsisten ketika mengukur gejala yang sama. $^{16}$ Uji Reliabilitas menggunakan rumus Alpha

15 Ardial, Paradigma dan Model Penelitian Komunikasi, (Jakarta: Bumi Aksara, 2014), 54.

16 Basuki, Agus Tri dan Nano Prawoto, Analisis Regresi Dalam Penelitian Ekonomi \& Bisnis, (Jakarta: Raja Grafindo Persada, 2016), 40.
Cronbach, dengan bantuan SPSS 26. Instrumen dikatakan reliabel jika, nilai alpha $>0,7$.

Hasil analisis menunjukkan masingmasing variabel Frekuensi (X1), Durasi (X2), Intensitas (X3) dan Keputusan Pembelian (Y) memiliki nilai alpha > 0,70. Sehingga instrumen penelitian dikatakan reliabel.

\section{Uji Korelasi}

Uji korelasi digunakan ntuk mengetahui apakah terdapat hubungan antara variabel $\mathrm{X}$ dengan masing-masing indikator dari variabel Y. Menggunakan rumus Korelasi Pearson's Product Moment. Menurut Sugiyono (2010), jika:

- Nilai interval r 0,00 - 0,199 maka, tingkat hubungan sangat rendah

- Nilai interval r 0,20 - 0,399 maka, tingkat hubungan rendah

- Nilai interval r 0,40 - 0,599 maka, tingkat hubungan sedang

- Nilai interval r 0,60 - 0,799 maka, tingkat hubungan kuat

- Nilai interval r 0,80 - 1,000 maka, tingkat hubungan sangat kuat

Hasil analisis menunjukkan masingmasing variabel Frekuensi (X1), Durasi (X2), Intensitas (X3) dan Keputusan Pembelian (Y) memiliki r yang beragam akan tetapi masuk ke dalam kategori memiliki hubungan sedang dan hubungan kuat, yakni memiliki nilai interval $r$ 0,40 0,599 dan $0,60-0,799$.

\section{Uji Regresi Linier Berganda}

Uji regresi untuk meriset apakah memang ada hubungan atau pengaruh yang signifikan atau tidak antara sebab- 
akibat tersebut, maka digunakan rumus regresi. ${ }^{17}$ Terdapat 2 macam analisis regresi, yakni regresi linier sederhana dan regresi linier berganda. Regresi linier sederhana untuk penelitian yang memiliki variabel independen terdiri dari satu, sedangkan regresi linier berganda dilakukan untuk penelitian yang menggunakan variabel independen dua atau lebih.

Pada penelitian ini, peneliti menggunakan 'Regresi Linier Berganda' karena peneliti menggunakan tiga variabel independen (bebas) yakni frekuensi, durasi dan intensitas. Rumus persamaan umum regresi linier berganda yang digunakan ialah:

$$
\mathrm{Y}=\mathrm{a}+\mathrm{b} 1 \mathrm{X} 1+\mathrm{b} 2 \mathrm{X} 2+\mathrm{b} 3 \mathrm{X} 3
$$

Keterangan:

$\mathrm{a}=$ nilai konstanta

b1X1 = koefisien regresi variabel X1

b2X2 = koefisien regresi variabel X2

b3X3 = koefisien regresi variabel X3

Tabel 1. Hasil Uji Regresi Linier Berganda

\section{Coefficients $^{\mathbf{a}}$}

\begin{tabular}{|c|c|c|c|c|c|}
\hline \multirow{2}{*}{ Model } & \multicolumn{2}{|c|}{$\begin{array}{c}\text { Unstandardized } \\
\text { Coefficients }\end{array}$} & $\begin{array}{c}\text { Standardized } \\
\text { Coefficients }\end{array}$ & \multirow{2}{*}{ T } & \multirow{2}{*}{ Sig. } \\
\cline { 2 - 5 } & $\mathrm{B}$ & $\begin{array}{c}\text { Std. } \\
\text { Error }\end{array}$ & Beta & & \\
\hline 1 (Constant) & 32,942 & 1,858 & & 17,733 & 0,000 \\
Frekuensi & 1,598 & 0,481 & 0,298 & 3,320 & 0,001 \\
Durasi & 1,469 & 0,497 & 0,312 & 2,958 & 0,004 \\
Intensitas & 1,751 & 0,469 & 0,320 & 3,732 & 0,000 \\
\hline
\end{tabular}

Dependent Variable: Keputusan Pembelian Sumber: Hasil Olah Data, 2020

Berdasarkan tabel hasil uji regresi dengan menggunakan SPSS 26, maka

17 Burhan Bungin, Metodologi Penelitian Kuantitatif: Komunikasi, Ekonomi, dan Kebijakan Publik Serta Ilmu-Ilmu Sosial Lainnya, (Jakarta: Kencana, 2006) 37. rumus persamaan regresi linier berganda yang dihasilkan ialah sebagai berikut:

$\mathrm{Y}=32,942+1,598 \mathrm{X} 1+1,469 \mathrm{X} 2+$

$$
1,751 \times 3
$$

- Nilai a $=32,942$. Jika frekuensi, durasi dan intensitas nilainya 0 , maka keputusan pembelian memiliki nilai sebesar 32,942

- $\quad$ b Frekuensi $=1,598$. Jika frekuensi ditingkatkan menjadi 1 satuan, maka keputusan pembelian akan meningkat sebesar 1,598

- $\mathrm{b}$ Durasi $=1,469$. Jika durasi ditingkatkan menjadi 1 satuan, maka keputusan pembelian akan meningkat sebesar 1,469

- $\quad$ b Intensitas $=1,751$. Jika intensitas ditingkatkan menjadi 1 satuan, maka keputusan pembelian akan meningkat sebesar 1,751

\section{Uji Hipotesis}

\section{a. Uji Statistik F}

Uji F untuk mengetahui pengaruh dari keseluruhan variabel independen secara simultan/bersama-sama. Jika F hitung > F tabel, maka seluruh variabel independen memiliki pengaruh terhadap variabel dependen secara simultan. Diketahui $\mathrm{N}=100$, nilai signifikasi $=5 \%$, jumlah variabel independen $=3$. Maka, diketahui nilai $\mathrm{F}$ tabel ialah 2,699. 
Tabel 2. Hasil Uji Simultan (Uji F)

\begin{tabular}{|c|c|c|c|c|c|}
\hline \multicolumn{6}{|l|}{ ANOVA $^{\mathrm{a}}$} \\
\hline Model & $\begin{array}{l}\text { Sum of } \\
\text { Squares }\end{array}$ & Df & $\begin{array}{l}\text { Mean } \\
\text { Square }\end{array}$ & $\mathrm{F}$ & Sig. \\
\hline 1 Regression & 4721,475 & 3 & 1573,825 & 79,722 & $0,000^{b}$ \\
\hline Residual & 1895,165 & 96 & 19,741 & & \\
\hline Total & 6616,640 & 99 & & & \\
\hline
\end{tabular}

Sumber: Hasil Olah Data, 2020

Hasil analisis menunjukkan nilai $\mathrm{F}$ hitung $=79,722$. Sehingga, variabel frekuensi (X1), durasi (X2) dan intensitas (X3) memiliki pengaruh terhadap keputusan pembelian (Y) secara simultan.

\section{b. Uji Statistik t}

Uji t untuk mengetahui pengaruh dari masing-masing variabel independen secara parsial/sendirisendiri. Jika $\mathrm{t}$ hitung $>\mathrm{t}$ tabel, maka masing-masing variabel independen memiliki pengaruh terhadap variabel dependen secara parsial.

$\mathrm{DF}=\mathrm{N}-\mathrm{k}-1=100-3-1=96$

$\mathrm{DF}=96$, nilai signifikan $0,05: 2=$ 0,025 . Maka diketahui nilai $t$ tabel ialah 1,985 .

Tabel 3. Hasil Uji Parsial (Uji t)

\begin{tabular}{|c|c|c|c|c|c|}
\hline \multirow{2}{*}{ Model } & \multicolumn{2}{|c|}{$\begin{array}{c}\text { Unstandardized } \\
\text { Coefficients }\end{array}$} & $\begin{array}{c}\text { Standardized } \\
\text { Coefficients }\end{array}$ & \multirow{2}{*}{$\mathrm{T}$} & \multirow{2}{*}{ Sig. } \\
\cline { 2 - 5 } & $\mathrm{B}$ & $\begin{array}{c}\text { Std. } \\
\text { Error }\end{array}$ & Beta & & \\
\hline 1 (Constant) & 32,942 & 1,858 & & 17,733 & 0,000 \\
Frekuensi & 1,598 & 0,481 & 0,298 & 3,320 & 0,001 \\
Durasi & 1,469 & 0,497 & 0,312 & 2,958 & 0,004 \\
Intensitas & 1,751 & 0,469 & 0,320 & 3,732 & 0,000 \\
\hline
\end{tabular}

Dependent Variable: Keputusan Pembelian Sumber: Hasil Olah Data, 2020
Berdasarkan tabel, nilai $\mathrm{t}$ hitung variabel frekuensi ialah 3,320; variabel durasi ialah 2,958; dan variabel intensitas adalah 3,732. Hasil analisis menunjukkan nilai $\mathrm{t}$ hitung $>\mathrm{t}$ tabel. Sehingga, variabel frekuensi (X1), durasi (X2) dan intensitas (X3) memiliki pengaruh terhadap keputusan pembelian (Y) secara simultan.

\section{Pembahasan}

Frekuensi memiliki pengaruh positif terhadap keputusan pembelian. Sesuai dengan teori menurut Wells, dkk. ${ }^{18}$ bahwa konsumen tidak akan cukup untuk mengingat pesan dan membangun kepercayaan dengan suatu merek jika hanya terkena satu kali atau dua kali terpaan (melihat, membaca, mendengar iklan).

Durasi memiliki pengaruh positif terhadap keputusan pembelian. Semakin lama durasi yang dihabiskan oleh audiens ketika melihat, membaca, mendengar iklan, maka semakin lama audiens terpapar iklan, semakin tinggi pula tingkat keingatannya dan pengetahuannya terhadap iklan. Jika audiens menonton tayangan iklan sampai selesai, kemungkinan besar audiens akan memperoleh informasi sepenuhnya yang disampaikan oleh iklan tersebut

Intensitas memiliki pengaruh positif terhadap keputusan pembelian. Semakin besar tingkat perhatian audiens saat menonton iklan, dapat menyebabkan

${ }^{18}$ William Wells, Sandra Moriarty and John Burnett, Advertisig Principles \& Practice 7th Edition. (New Jersey: Pearson Prentice Hall, 2006). 
semakin tersampainya pesan-pesan yang ingin disampaikan oleh iklan tersebut, sehingga berpengaruh terhadap keinginan seseorang untuk memutuskan membeli produk yang diiklankan atau tidak.

Jika dikaitkan dengan teori S-O-R, maka Stimulus merupakan esan yang terkandung dalam iklan Nacific di Instagram. Sedangkan, organisme merupakan seseorang yang menerima pesan tersebut yakni followers akun @ nacificofficial.id.Dan respons merupakan perubahan sikap yang diharapkan pemberi stimulus, yakni keputusan pembelian.

Respon yang dimiliki masing-masing individu berbeda tergantung dari bagaimana proses yang terjadi pada individu itu sendiri. Proses yang terjadi pada individu melewati tiga tahap yakni perhatian, pengertian dan penerimaan. Pada proses perhatian, kehadiran Jang Hansol lebih menarik perhatian daripada iklan Nacific yang hanya menggunakan simbol berupa teks, warna, gambar/video produk. Pada proses pengertian, audiens berusaha memahami, mencerna isi pesan teks dengan memberikan pengertian pada iklan. Dan yang terakhir, proses penerimaan : Audiens dapat menerima maupun menolak isi pesan yang disampaikan, tentu hal ini tergantung dari persepsi masing-masing individu menginterpretasikan iklan tersebut.

\section{Kesimpulan}

Kesimpulan yang dapat diambil dari penelitian ini ialah, bahwa Frekuensi $\left(\mathrm{X}_{1}\right)$, Durasi $\left(\mathrm{X}_{2}\right)$ dan Intensitas $\left(\mathrm{X}_{3}\right)$, masingmasing memiliki pengaruh terhadap keputusan pembelian yang terdiri dari: pilihan produk $\left(\mathrm{y}_{1}\right)$, pilihan merek $\left(\mathrm{y}_{2}\right)$, pilihan penyalur $\left(\mathrm{y}_{3}\right)$, jumlah pembelian $\left(\mathrm{y}_{4}\right)$, waktu pembelian ( $\left.\mathrm{y}_{5}\right)$ dan metode pembayaran ( $\left.\mathrm{y}_{6}\right)$. Sehingga, terpaan iklan (frekuensi, durasi dan intensitas) Nacific versi Jang Hansol di Instagram, memiliki pengaruh positif baik signifikan secara simultan/bersama-sama maupun secara parsial/masing-masing terhadap keputusan pembelian produk Nacific yang diiklankan.

Dengan hasil yang demikian diharapkan pihak Nacific meningkatkan interaksi pada akun sosial media Instagram, semakin komunikatif kepada pengguna yang memberikan pertanyaan seputar produk di kolom komentar maupun di direct message. Untuk masyarakat diharapkan untuk menggunakan media sosial dengan bijak dan memanfaatkannya untuk kegiatan yang positif. Tetap berhati-hati karena maraknya cyber crime. Sedangkan untuk peneliti selanjutnya disarankan dapat melanjutkan penelitian ini dengan menggunakan variabel independen yang berbeda seperti brand ambassador yaitu Jang Hansol. Maupun dengan menggunakan subyek penelitian yang lebih banyak dan memiliki populasi yang luas untuk mengetahui pengaruh yang ditimbulkan pada khalayak luas.

\section{Daftar Pustaka}

Achmad, Z. A., \& Setiyanti O. W. The Effectiveness of Use of Soundcloud Application for Promoting Pop Punk Songs and Music. Bali International Seminar on Science and Technology. 
(Desember, 2012): 59-64. www.engadget.com/2012/12/07/edito rial-

Ambar. 20 Pengertian Media Sosial Menurut Para Ahli. (Januari 12, 2020).

https://pakarkomunikasi.com/pengerti an-media-sosial-menurut-para-ahli.

APJII (Asosiasi Penyelenggara Jasa Insternet Indonesia). Hasil Survei Penetrasi dan Perilaku Pengguna Insternet Indonesia 2018. (Januari 8, 2020).

https://apjii.or.id/content/read/39/410

/Hasil-Survei-Penetrasi-dan-

Perilaku-Pengguna-Internet-

Indonesia-2018.

Ardial. Paradigma dan Model Penelitian Komunikasi. Jakarta: Bumi Aksara, 2014.

Basuki, Agus Tri \& Nano Prawoto. Analisis Regresi Dalam Penelitian Ekonomi \& Bisnis. Jakart: Raja Grafindo Persada, 2016.

Bungin, Burhan. Metodologi Penelitian Kuantitatif: Komunikasi, Ekonomi, dan Kebijakan Publik Serta Ilmu-Ilmu Sosial Lainnya. Jakarta: Kencana, 2006.

Damiati, dkk. Perilaku Konsumen. Depok: Rajawali Pers, 2017.

Jaiz, Muhammad. Dasar-Dasar Periklanan. Yogyakarta: Graha Ilmu, 2014.

Kotler, Philip \& Gary Armstrong. PrinsipPrinsip Pemasaran. Jilid 2. Jakarta: Erlangga, 2001.
Kotler, Philip \& Kevin Lane Keller. Manajemen Pemasaran. Jilid 1 Edisi ke-13. Jakarta: Erlangga, 2012.

Kurniawan, David. Kelebihan dan Kekurangan Instagram sebagai Media Promosi. (Februari 20, 2020). https://exrush.com/kelebihan-dankekurangan-instagram-sebagai media promosil

Lee, Monle \& Carla Johnson. PrinsipPrinsip Pokok Periklanan dalam Perspektif Global. Jakarta: Kencana Prenada Media, 2011.

Markerter, Elite. Membuat Iklan di Instagram untuk Mempromosikan Bisnis Anda. (Januari 13, 2020). https://elitemarketer.id/socialmedia/membuat-iklan-di-instagramuntuk mempromosikan-bisnisandal

Masharyono, Diyah Setyorini \& Intan Lina Katrin. Pengaruh Promosi Terhadap Keputusan Pembelian di Restoran Javana Bistro Bandung. Universitas Pendidikan Indonesia, 2016.

McQuail, Denis. Teori Komunikasi Massa: Suatu Pengantar. Jakarta: Erlangga, 1991.

Morissan. Periklanan: Komunikasi Pemasaran Terpadu. Jakarta: Kencana Prenada Media, 2010.

Mudassir, Rayful. Daftar Pengguna Instagram Terbanyak di Dunia, Indonesia di Urutan Berapa? $\begin{array}{lll}\text { (Januari 2020). } & \text { 8, }\end{array}$ https://teknologi.bisnis.com/read/201 90629/84/939306/dafta pengguna- 
instagram-terbanyak-di-dunia-

indonesia-di-urutan-berapa.

Munir. Pembelajaran Digital. Bandung: Alfabeta, 2017.

Nasrullah, Rulli. Teori dan Riset Media Siber (Cybermedia). Jakarta: Kencana Prenada Media, 2014.

Nilapradnya, Andara D. Pengaruh Iklan Melalui Media Sosial Instagram terhadap Keputusan Pembelian Loffle di Kota Semarang. Program Studi Ilmu Komunikasi. Fakultas Ilmu Komunikasi. Universitas Katolik Soegijapranata Semarang, 2018.

Pahlevi. Kelebihan dan Kekurangan Instagram sebagai Media Pemasaran Online. Februari 20, 2020. https://www.pahlevi.net/kelebihandan-kekurangan-instagram/

Paramitha, Nadya. 5 Fitur Terbaru dari Platform Media Sosial Favorit Ini Bergun Banget!/ Januari 1, 2020. https://journal.sociolla.com/lifestyle/fi tur-baru-platformmedia-sosial/

Sendari, Anugrah Ayu. Instagram Adalah Platform Berbagi Foto dan Video, Ini Deretan Fitur Canggihnya. Januari 4, 2020.

https://www.liputan6.com/tekno/read/390 6736/inst gram-adalahplatformberbagi-foto-dan-video-inideretan-fitur-canggihnya.

Shauma, A., \& Achmad, Z. A. Efektivitas Iklan Politik di Televisi (Studi Deskriptif Kuantitatif Efektifitas Iklan Politik Aburizal Bakrie Versi Motivasi Anak Indonesia Pada
Pemilih Pemula di Surabaya). Jurnal Imu Komunikasi 7 no. 2 (Oktober 2015): 1-10.

Shimp, Terence A. Periklanan \& Promosi: Aspek Tambahan Komunikasi Pemasaran

Terpadu. Jilid 1 ed. 5. Jakarta: Erlangga, 2003.

Sugiyono. Metode Penelitian Bisnis (Pendekatan Kuantitatif dan R\&D). Bandung: Alfabeta, 2010.

Sutarman. Pengantar Teknologi Informasi. Jakarta: Bumi Aksara, 2012.

Uchjana, Onong Effendy. Ilmu, Teori dan Filsafat Komunikasi. Bandung: Citra Aditya Bakti, 2000.

Veren, Rachel Vanadya. Pengaruh Iklan pada Social Media Platform Instagramterhadap Keputusan Pembelian (Survei pada Pengikut Sociolla). Program Studi Ilmu Komunikasi. Fakultas Ilmu Komunikasi. Universitas Multimedia Nusantara Tangerang, 2019.

Wells, William, Sandra Moriarty \& John Burnett. Advertisig Principles \& Practice $7^{\text {th }}$ Edition. New Jersey: Pearson Prentice Hall, 2006. 